Publicação organizada pelo Programa de

Mestrado Profissional Stricto Sensu em

Engenharia Civil da Universidade São Judas

Volume 01 - Edição 01

Janeiro - Dezembro de 2018

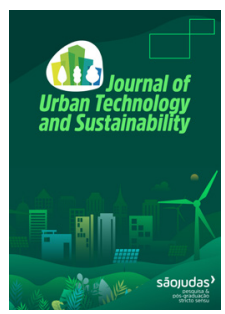

\title{
Application of graphene oxide in cementitious composites for cement content reduction
}

Renan P. Salvadora,, Roberto Munhoz Buenoa, Dimas Alan Strauss Ramboa, Sandro Martinia

a Department of Civil Engineering, São Judas Tadeu University, 546 Taquari St., São Paulo, 03166-000, Brazil.

\section{Article info \\ Received 25 May 2018 \\ Received in revised form 13 \\ August 2018 \\ Accepted 21 August 2018 \\ Keywords \\ Cementitious composites \\ Graphene oxide \\ Cement hydration \\ Mechanical properties \\ Sustainability}

\begin{abstract}
The concern about $\mathrm{CO}_{2}$ emissions derived from the construction industry has brought attention to the development of sustainable construction materials and processes. Admixtures based on graphene oxide have the potential to enhance mechanical properties and durability of cementitious composites. In this context, an experimental program was conducted to evaluate how graphene oxide may be used to reduce cement content in concretes, maintaining the same mechanical properties as control concretes. Hydration kinetics were evaluated by isothermal calorimetry and XRD/Rietveld and mechanical properties were evaluated by compressive strength. Results indicate that graphene oxide provided a faster hydration rate until $24 \mathrm{~h}$ and generates a larger amount of $\mathrm{C}-\mathrm{S}-\mathrm{H}$ gel, increasing mechanical strength of the matrix. The addition of graphene oxide at $0.02 \%$ by cement weight, reductions of up to $15 \%$ in cement content may be obtained, maintaining the same compressive strength as the control matrices. From this research, a reduction in cement content to obtain more

sustainable materials and processes. may be achieved.
\end{abstract}

\section{Aplicação de óxido de grafeno em compósitos cimentícios para redução do consumo de cimento}

\section{Informações}

Recebido 25 Maio 2018

Manuscrito revisado recebido

13 Agosto 2018

Aceito 21 Agosto 2018

Palavras-chave

Compósitos cimentícios

Óxido de grafeno

Hidratação de cimento

Propriedades mecânicas

Sustentabilidade

\section{Resumo}

A preocupação com as emissões de $\mathrm{CO}_{2}$ provenientes da indústria da construção tem trazido atenção para o desenvolvimento de materiais e processos sustentáveis. Aditivos à base de óxido de grafeno têm o potencial de melhorar as propriedades mecânicas e a durabilidade de compósitos cimentícios. Nesse contexto, foi avaliado como o óxido de grafeno pode ser utilizado para reduzir o consumo de cimento em concretos, mantendo as mesmas propriedades mecânicas de concretos controle. A cinética de hidratação foi avaliada por calorimetria isotérmica $r$ por DRX/Rietveld e a resistência mecânica foi avaliada por compressão axial. Os resultados indicam que o óxido de grafeno proporcionou uma taxa de hidratação mais rápida até 24 h e gerou uma maior quantidade de $\mathrm{C}-\mathrm{S}-\mathrm{H}$, aumentando a resistência mecânica da matriz. Com a adição de óxido de grafeno a 0,02\% sobre a massa de cimento, podem ser obtidas reduções de até $15 \%$ no consumo de cimento, mantendo a mesma resistência à compressão das matrizes de controle. A partir desta pesquisa, uma redução no consumo de cimento para a obtenção de materiais e processos mais sustentáveis pode ser obtida.

\section{Aplicación de óxido de grafeno en compósitos cementíceos para la reducción del consumo de cemento}

\section{Información}

Recibido 25 Mayo 2018

Manuscrito revisado recibido

13 Agosto 2018

Aceptado 21 Agosto 2018

\section{Palabras clave}

Compósitos cementiceos Óxido de grafeno

Hidratación de cemento

Propiedades mecánicas

Sostenibilidad

\section{Resumen}

La preocupación por las emisiones de $\mathrm{CO}_{2}$ derivadas de la industria de la construcción ha llamado la atención para el desarrollo de materiales y procesos sostenibles. Aditivos basados en óxido de grafeno pueden mejorar las propiedades mecánicas y la durabilidad de los compositos cementicios. En este contexto, se ha evaluado como el óxido de grafeno puede reducir el contenido de cemento en hormigones, manteniendo las mismas propiedades mecánicas que hormigones control. La cinética de hidratación se evaluó mediante calorimetría isotérmica y DRX/Rietveld y las propiedades mecánicas se evaluaron mediante resistencia a la compresión. Los resultados indican que el óxido de grafeno aumentó la tasa de hidratación hasta las 24 h y generó una mayor cantidad de C-S-H, aumentando la resistencia mecánica de la matriz. Con la adición de óxido de grafeno al 0,02\% sobre la masa de cemento, se pueden obtener reducciones de hasta un 15\% en el contenido de cemento, manteniendo la misma resistencia a la compresión que la matriz control. A partir de esta investigación, se puede lograr una reducción del contenido de cemento para obtener materiales y procesos más sostenibles.

\footnotetext{
* Corresponding author at: Department of Civil Engineering, São Judas Tadeu University, 546 Taquari St., 03166-000 São Paulo, Brazil. 


\section{Introduction}

Portland cement is one of the major components in conventional concrete. Due to the clinkerization process, $\mathrm{CO}_{2}$ emissions generated by cement production are around $800 \mathrm{~kg} / \mathrm{ton}$ cement (HASANBEIGI; PRICE; LIN, 2012; HILLS; FLORIN; FENNELL, 2016). Extensive researches focus on the reduction of the $\mathrm{CO}_{2}$ footprint of construction materials, suchas the development of supplementary cementitious materials (LOTHENBACH; SCRIVENER; HOOTON, 2011), belitic binders (ÁVALOS-RENDÓN et al., 2018; SINYOUNG et al., 2017) and geopolymers (SELMANI et al., 2017).

Nanomaterials are often applied in cement-based composites in order to optimize their properties in the fresh and hardened states. Colloidal silica may improve the rheological behavior of fresh concrete due to its high surface area (SENFF et al., 2009) and reduce its porosity due to its pozzolanic effect (RUPASINGHE et al., 2017). Graphene oxide may be used to increase concrete strength and durability because it acts as nucleation sites for the precipitation of $\mathrm{C}-\mathrm{S}-\mathrm{H}$ phases and accelerates its formation (GHAZIZADEH et al., 2018).

Since graphene oxide enhances the cement hydration behavior at early ages and leads to increases in the compressive strength of the matrix, concretes may be produced with graphene oxide in order to reduce cement content in their composition, with no negative effect on the mechanical properties. In this context, the objective of this work is to evaluate the influence of graphene oxide on the hydration behavior of cementitious materials, focusing on the enhancement of hydration kinetics and mechanical strength development in order to reduce cement content in the mix design of concretes.

\section{Experimental methodology}

This research was conducted at the Laboratory of Civil Construction Engineering from São Judas Tadeu University. The characterization of hydration kinetics and phase evolution during hydration was performed in cement pastes to avoid the dilution of pastes by aggregates. On the other hand, the characterization of compressive strength was conducted in concrete specimens.

\subsection{Materials}

A CEM I 52.5R was used in this study. Distilled water and a superplasticizer based on a polycarboxylate solution (34\% of solid content) were used for cement pastes. Tap water, fine aggregate (fineness modulus $=2.2$; specific weight $=2.60 \mathrm{~g} / \mathrm{cm}^{3}$; unit weight $\left.=1.42 \mathrm{~g} / \mathrm{cm}^{3}\right)$ and coarse aggregate (dmax $=9.5 \mathrm{~mm}$; specific weight $=2.66 \mathrm{~g} / \mathrm{cm}^{3}$; unit weight $=1.47 \mathrm{~g} / \mathrm{cm}^{3}$ ) were used for concretes.

An aqueous dispersion of graphene oxide (GO) was used in the preparation of cement pastes and concretes. Its solid content was $0.40 \%$ by weight, its $\mathrm{pH}$ was 2.5 and the maximum particle size was equal to $10 \mu \mathrm{m}$.

\subsection{Composition and preparation of cement pastes}

Pastes were produced with water/cement (W/c) ratios equal to 0.30 and 0.45 . Superplasticizer was added at $0.3 \%$ by cement weight ( $\%$ bcw). GO was used at 0.05 and $0.20 \%$ bcw. Cement pastes were identified by 'w/c ratio'_superplasticizer'_GO content'. Pastes produced with no superplasticizer was identified by 'w/c ratio'_'REF'.

Cement pastes were prepared in batches of 200 g. Cement was added to water and homogenized for 1 min using an IKA RW 20 agitator coupled with a R1342 4-bladed stirrer at 1200 rpm. After that, superplasticizer was added and the mixture was homogenized for $1 \mathrm{~min}$ at $1200 \mathrm{rpm}$. Then, GO was added and the paste was mixed for $1 \mathrm{~min}$ at 2200 rpm. Finally, cement pastes were destined to isothermal calorimetry and X-ray diffraction.

\subsection{Composition and preparation of concretes}

Concrete was composed by cement, fine aggregate, coarse aggregate and water, whose respective relative masses were $1.00: 0.94: 1.97$ 0.35 (cement content equal to $581 \mathrm{~kg} / \mathrm{m}^{3}$ ) and $1.00: 1.20: 1.90: 0.40$ (cement content equal to $\left.509 \mathrm{~kg} / \mathrm{m}^{3}\right)$. Superplasticizer was added at $0.70 \%$ 
bcw and the dispersion of graphene oxide at 0.2\% bcw. Concrete mixes were identified by "cement content'_'w/c ratio'_ ‘GO content'.

Concretes were produced in batches of $30 \mathrm{~L}$ in a $150 \mathrm{~L}$ conventional concrete mixer. In order to provide an adequate dispersion of GO in concrete, the total amount of $\mathrm{GO}$ required to produce 30 $L$ of concrete was dispersed in a cement paste containing $2.0 \mathrm{~kg}$ of cement, $0.60 \mathrm{~kg}$ of water and superplasticizer at $0.30 \%$ bcw following the procedures from item 3.2. The amount of materials necessary to produce cement pastes was deducted from the amounts used for concrete production.

To fabricate concrete, coarse aggregate and 1/3 of the amount of water were added to the mixer and homogenized for 1 min. After that, cement and another $1 / 3$ of the amount of water were added and mixed for $2 \mathrm{~min}$. Then, fine aggregate and the remaining amount of water were added to the mixer and homogenized for 2 min. The last step consisted in adding superplasticizer and the cement paste containing the $\mathrm{GO}$ dispersion and mixing the concrete for 5 min. Once concrete production was finished, 15 cylindrical specimens measuring 10 $\mathrm{cm}$ in diameter and $20 \mathrm{~cm}$ in height were molded according to (ABNT, 2015).

\subsection{Test methods}

Isothermal calorimetry was performed to analyze the hydration behavior of cement pastes containing different GO contents. This test was conducted at $23^{\circ} \mathrm{C}$ during $24 \mathrm{~h}$ with $8.0 \mathrm{~g}$ of cement paste, using a TAMAir isothermal calorimeter.

Powder X-ray diffraction (XRD) was performed to analyze the phase evolution of cement pastes containing different $\mathrm{GO}$ contents during hydration. Tests were conducted in a PANalytical X'Pert PRO MPD Alpha1 powder diffractometer in reflection Bragg-Brentano $\theta / 2 \theta$ geometry equipped with an $X^{\prime}$ Celerator detector (active length of $2.122^{\circ}$ ) and a fixed divergence slit of $0.5 \mathrm{o}$. It operates with Ni-filtered CuK $\alpha$ radiation ( $\lambda=1.5418 \AA$ ) at $45 \mathrm{kV}$ and $40 \mathrm{~mA}$. Sample holders were cylindrical, with a diameter of $16 \mathrm{~mm}$ and a depth of $2.5 \mathrm{~mm}$. They were backloaded and spun at 2 revolutions per second.

Diffraction patterns were recorded from $5^{\circ} 2 \theta$ to $70{ }^{\circ} 2 \theta$, using a step width of $0.017{ }^{\circ} 2 \theta$ and 100 seconds per step. They were analyzed quantitatively by Rietveld refinement using the software X'Pert HighScore Plus with the structure models shown in (SALVADOR et al., 2015). Amorphous content was determined by the external standard method (SNELLINGS, 2015) to provide an indirect assessment of the $\mathrm{C}-\mathrm{S}-\mathrm{H}$ amount contained in the matrix using alumina powder (SRM 676a, from NIST) as a standard reference material. The hydration of cement pastes was stopped by solvent exchange at $24 \mathrm{~h}$ after their preparation. This method was employed because it does not affect the stability and crystallinity of hydrated aluminate phases, as indicated by (MACIEL et al., 2018).

Compressive strength was determined from direct compression tests performed in cylindrical concrete specimens measuring $100 \mathrm{~mm}$ in diameter and $200 \mathrm{~mm}$ in length. Tests were conducted in a Shimadzu Universal Testing Machine, model UH$\mathrm{F} 1000 \mathrm{kN}$, at a loading rate equal to $0.45 \mathrm{MPa} / \mathrm{min}$, according to (ABNT, 2018). Three specimens were tested at each age (1, 3, 7, 28 and 91 days).

\section{Results and discussion}

Figure 1 shows the heat flow curves of cement pastes from 0 to 24 h. Figure 1.a and 1.b represent the pastes produced with $\mathrm{w} / \mathrm{c}$ equal to 0.30 and 0.45 , respectively. Table 1 summarizes the characteristic points of the heat flow curves, determined according to (SALVADOR et al., 2016). The conclusions derived from this analysis are presented subsequently.

Analyzing pastes 0.30_REF and 0.30_SP, it is possible to observe a retarding effect of the superplasticizer. The same effect is observed in pastes produced with $\mathrm{w} / \mathrm{c}$ ratio equal to 0.45 . However, when GO is used, induction periods become shorter, indicating that this addition accelerates the onset of cement hydration. In addition, GO accelerates reaction rates, narrowing the main hydration peak. By doing so, higher maximum intensities and higher degrees of 


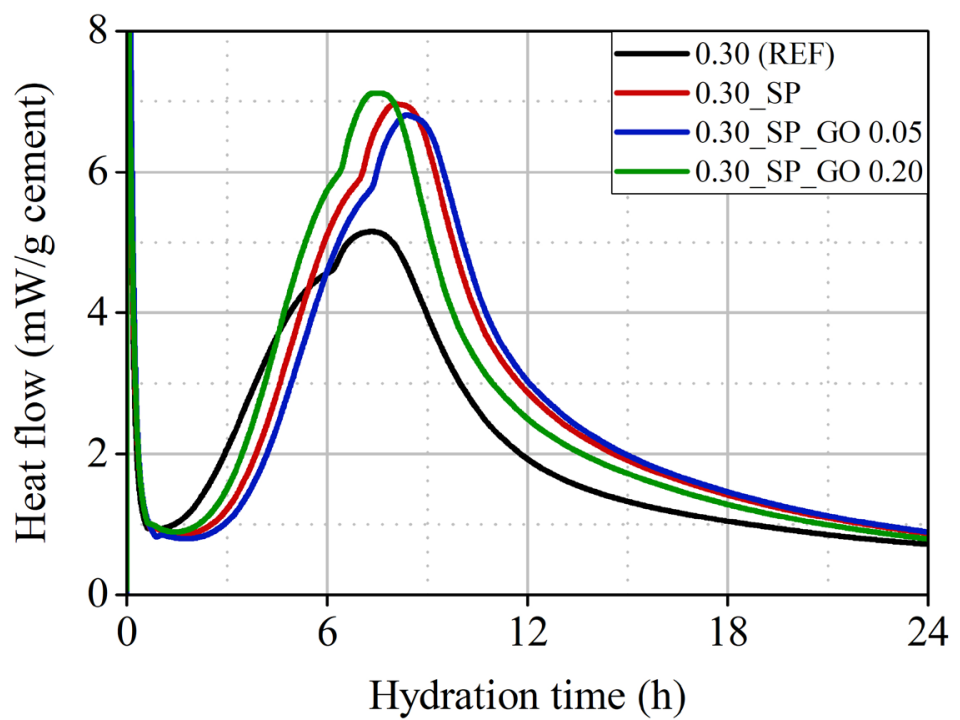

(a)

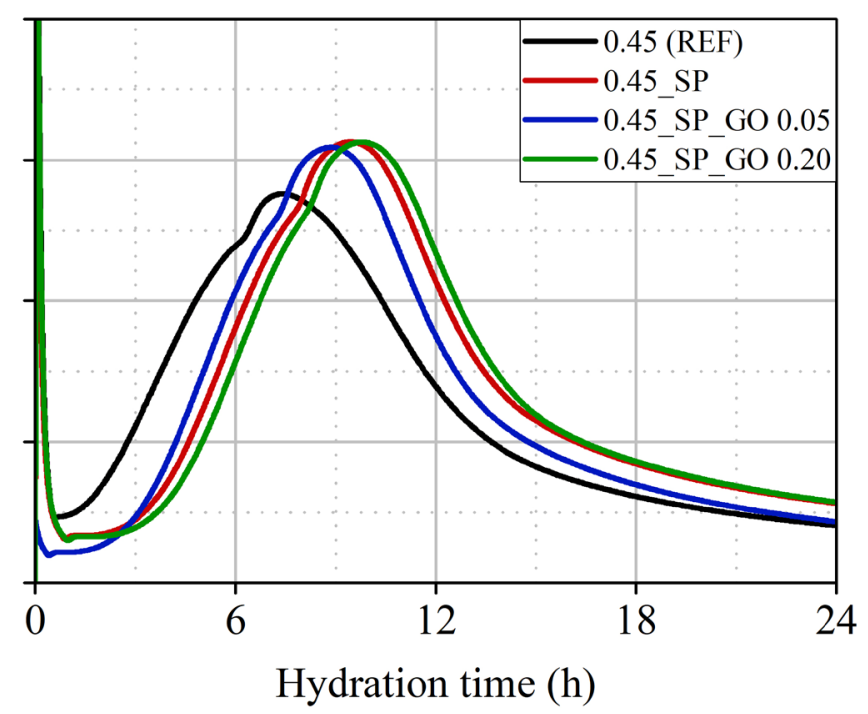

(b)

Fig. 1. Heat flow curves of cement pastes containing graphene oxide produced with w/c ratio equal to 0.30 (a) and 0.45 (b).

hydration at $24 \mathrm{~h}$ are achieved.

The overall acceleration on the hydration rate caused by GO occurs due to its elevated specific surface. GO is functionalized with carboxylate ions, serving as a nucleation site for the precipitation of silicate hydrates (GHAZIZADEH et al., 2018). Therefore, C-S-H nuclei may nucleate on the surface of GO nanoparticles, accelerating alite hydration and mechanical strength gain.

From the XRD results presented in fig. 2, a clear influence of GO on alite hydration is observed. GO leads to a higher consumption of alite, increasing portlandite contents. As alite is consumed at a greater extent, a larger amount of amorphous phases is obtained in pastes produced with GO, indicating that $\mathrm{C}-\mathrm{S}-\mathrm{H}$ formation is enhanced. $\mathrm{GO}$ does not present a significant influence on aluminate hydration, as may be observed in ettringite amounts, which was similar in both pastes.
Figure 3 presents the results of compressive strength at the ages of 1, 3, 7, 28 and 91 days. Comparing concretes 581_0.35 and 581_0.35_GO 0.02 , compressive strength at 1 day is $13 \%$ higher when $\mathrm{GO}$ is employed. At 91 days, the increase in compressive strength reaches $24 \%$. The same tendency is observed in concretes 509_0.40 and 509_0.40_GO 0.02.

Furthermore, the most important fact to notice is that concrete 509_0.40_GO 0.02 presents higher values of compressive strength at advanced ages than concrete 581_0.35. At 91 days, compressive strength of concrete 509_0.40_GO 0.02 is 15\% higher than concrete 581_0.35, even though the latter concrete contains 14\% more cement and lower w/c ratio. This means that GO may be used in concretes designed with lower cement content and higher $\mathrm{w} / \mathrm{c}$ ratio in order to maintain the

Table 1. Analysis of the heat flow curves obtained with cement pastes.

\begin{tabular}{ccccc}
\hline Paste & $\begin{array}{c}\text { Induction } \\
\text { period }(\mathbf{h})\end{array}$ & $\begin{array}{c}\text { Slope acceleration } \\
(\mathbf{m W / g . h})\end{array}$ & $\begin{array}{c}\text { Maximum heat flow } \\
(\mathbf{m W / g})\end{array}$ & $\begin{array}{c}\text { Energy released until 24 h } \\
(\mathbf{J} / \mathbf{g})\end{array}$ \\
\hline O.30 (REF) & 2.0 & 1.09 & 5.15 & 185.9 \\
O.30_SP & 3.2 & 1.57 & 6.96 & 227.8 \\
O.30_SP_GO 0.05 & 3.5 & 1.49 & 6.81 & 226.8 \\
O.30_SP_GO 0.20 & 2.8 & 1.69 & 7.11 & 224.5 \\
O.45 (REF) & 1.8 & 1.01 & 5.52 & 218.3 \\
O.45_SP & 2.9 & 1.20 & 6.26 & 233.4 \\
O.45_SP_GO 0.05 & 2.9 & 1.21 & 6.18 & 230.4 \\
O.45_SP_GO 0.20 & 3.9 & 1.18 & 6.25 & 233.0 \\
\hline
\end{tabular}




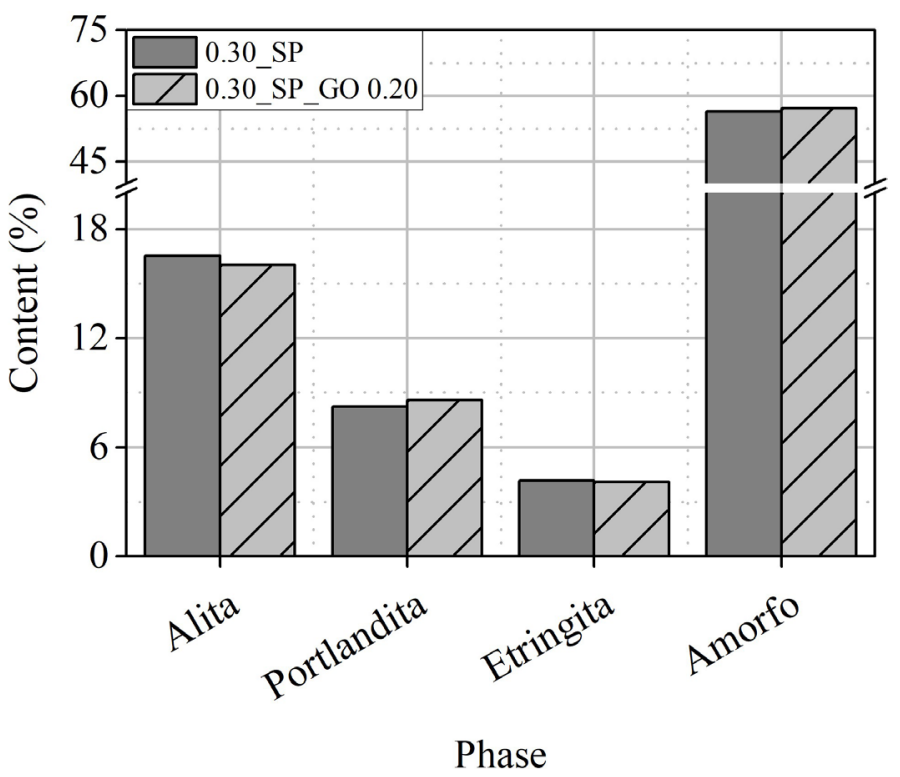

Fig. 2. Phase contents of cement pastes produced with and without graphene oxide.

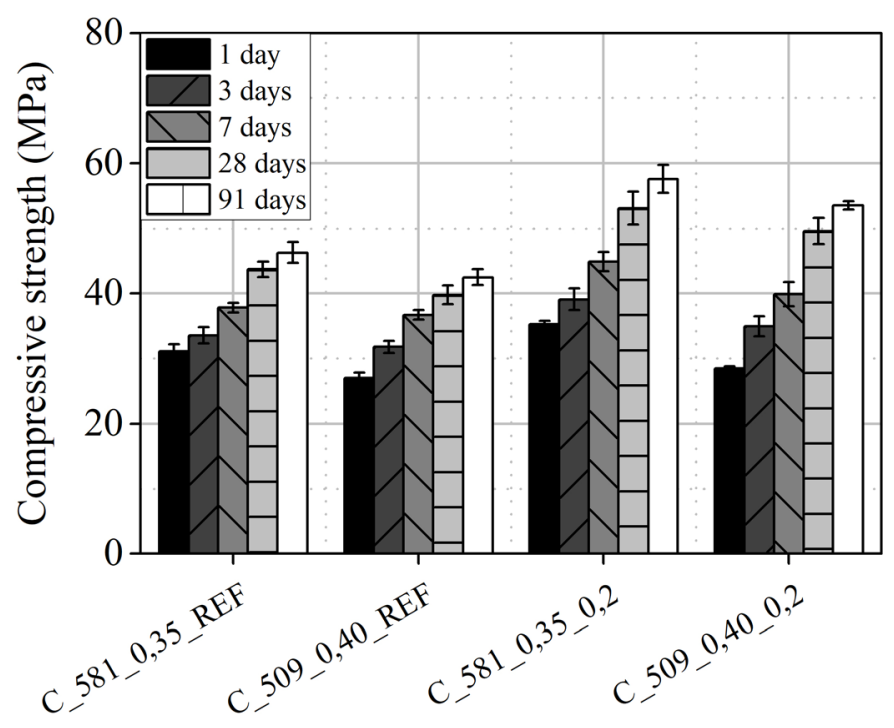

Concrete mix

Fig. 3. Compressive strength of concretes produced with and without graphene oxide at 1, 3, 7, 28 and 91 days.

same strength class as concretes containing larger cement amounts. Therefore, more sustainable concrete designs may be achieved using GO, since reductions in cement contents may be reduced with no negative influence on compressive strength.

\section{Conclusions}

The following conclusions may be drawn according to the results obtained from the experimental program conducted:
- Cement pastes produced with GO presented faster hydration kinetics when compared to reference pastes. GO induces shorter induction periods, faster reaction rates and leads higher degrees of hydration until $24 \mathrm{~h}$.

- GO enhances alite consumption and the consequent formation of $\mathrm{C}-\mathrm{S}-\mathrm{H}$.

- Concretes produced with GO were characterized by higher compressive strengths. Increases in compressive strength reached 13 and 24\% at the ages of 1 and 91 days, respectively.

- The use of GO in cementitious composites leads to more sustainable concrete designs, since GO may contribute to reduce cement content in concrete formulations with no negative effect on compressive strength.

\section{Acknowledgements}

Authors would like to thank São Judas Tadeu University for financial support. Thanks are extended Lafarge-Holcim for providing cement.

\section{References}

ASSOCIAÇ̃̃O BRASILEIRA DE NORMAS TÉCNICAS. ABNT NBR 5738: Concreto - Procedimento para moldagem e cura de corpos de prova. Rio de Janeiro: ABNT, 2015.

ASSOCIAÇÃO BRASILEIRA DE NORMAS TÉCNICAS. ABNT NBR 5739: Concreto - Ensaio de compressão de corpos de prova cilíndricos. Rio de Janeiro: ABNT, 2018.

ÁVALOS-RENDÓN, T. L. et al. Synthesis of belite cements at low temperature from silica fume and natural commercial zeolite. Materials Science and Engineering B: Solid-State Materials for Advanced Technology, v. 229, n. November 2017, p. 79-85, 2018.

GHAZIZADEH, S. et al. Understanding the behaviour of graphene oxide in Portland cement paste. Cement and Concrete Research, v. 111, n. June, p. 169-182, 2018.

HASANBEIGI, A.; PRICE, L.; LIN, E. Emerging energyefficiency and $\mathrm{CO}_{2}$ emission-reduction technologies 
for cement and concrete production: A technical review. Renewable and Sustainable Energy Reviews, v. 16, n. 8, p. 6220-6238, 2012.

HILLS, T.; FLORIN, N.; FENNELL, P. S. Decarbonising the cement sector: A bottom-up model for optimising carbon capture application in the UK. Journal of Cleaner Production, v. 139, p. 13511361, 2016.

LOTHENBACH, B.; SCRIVENER, K.; HOOTON, R. D. Supplementary cementitious materials. Cement and Concrete Research, v. 41, n. 12, p. 1244-1256, 2011.

MACIEL, M. H. et al. Monitoring of Portland cement chemical reaction and quantification of the hydrated products by XRD and TG in function of the stoppage hydration technique. Journal of Thermal Analysis and Calorimetry, n. September, 2018.

RUPASINGHE, M. et al. Investigation of strength and hydration characteristics in nano-silica incorporated cement paste. Cement and Concrete Composites, v. 80, p. 17-30, 2017.

SALVADOR, R. P. et al. Early age hydration of cement pastes with alkaline and alkali-free accelerators for sprayed concrete. Construction and Building Materials, v. 111, p. 386-398, 2015.

SALVADOR, R. P. et al. Parameters controlling early age hydration of cement pastes containing accelerators for sprayed concrete. Cement and Concrete Research, v. 89, p. 230-248, 2016.

SELMANI, S. et al. Effects of metakaolin addition on geopolymer prepared from natural kaolinitic clay. Applied Clay Science, v. 146, p. 457-467, 2017.

SENFF, L. et al. Effect of nano-silica on rheology and fresh properties of cement pastes and mortars. Construction and Building Materials, v. 23, n. 7, p. 2487-2491, 2009.

SINYOUNG, S. et al. Synthesis of belite cement from nano-silica extracted from two rice husk ashes.
Journal of Environmental Management, v. 190, p. 53-60, 2017.

SNELLINGS, R. X-ray powder diffraction applied to cement. In: SCRIVENER, K. L.; SNELLINGS, R.; LOTHENBACH, B. (Eds.). A Practical Guide to Microstructural Analysis of Cementitious Materials. 1st. ed. Boca Raton: CRC Press, 2015. p. 107-176. 